\title{
Aggregation in cattle dung-colonizing insect communities
}

\author{
Richard Wall, Colin Lee \\ From Parasite infections of domestic animals in the Nordic countries - emerging threats and challenges. \\ The 22nd Symposium of the Nordic Committee for Veterinary Scientific Cooperation (NKVet) \\ Helsinki, Finland. 7-9 September 2008
}

\section{Background}

Ruminant dung is a highly ephemeral, patchily distributed resource, which is utilized by a diverse community of invertebrate species. This ecologically important community may be affected adversely by insecticide and endectocide residues in the faeces of treated cattle. The aim of the present work was to quantify the aggregation of the insects colonising cow-dung in cattle pastures and test the hypothesis that the dung-pat community assemblage observed is the result of stochastic colonization events.

\section{Methods}

Fresh dung from dairy cattle was used to construct arrays of standardised, $1.5 \mathrm{~kg}$, artificial cow pats in cattle pastures. Batches of ten pats were placed out each week for 24 weeks, between May and October in 2001. Pats were left exposed in the field for seven days, to allow colonisation. Pats were then brought back to the laboratory and insect colonizers were collected and identified.

\section{Results}

Individual pats contained on average, only half the number of insect taxa present in an entire batch put out at any one time. Among six representative taxa of Diptera and four of Coleoptera, significant levels of intraspecific aggregation were observed in all but one (Mesembina meridiana), with the abundance of most taxa within pats approximating a negative binomial distribution. A simulation analysis was used to show that the observed relative frequency of taxa within pats does not differ from that expected by chance if colonisation is a

Veterinary Parasitology \& Ecology Group, School of Biological Sciences, University of Bristol, Woodland Road, Bristol, BS8 1UG, UK random binomial event in which each species colonises a pat independently of all other species.

\section{Conclusion}

The highly aggregated distributions observed in this study highlight the need for relatively large sample sizes when attempting to assess the abundance and distribution of individual taxa in cow dung. In addition, the results suggest that the aggregated populations of even highly abundant insects will be more susceptible to the deleterious effects of insecticidal residues in dung than if they were evenly distributed, if by chance they colonize a pat containing insecticidal residues from a recently treated animal.

Published: 13 October 2010

doi:10.1186/1751-0147-52-S1-S16

Cite this article as: Wall and Lee: Aggregation in cattle dung-colonizing insect communities. Acta Veterinaria Scandinavica 2010 52(Suppl 1):S16.

Submit your next manuscript to BioMed Central and take full advantage of:

- Convenient online submission

- Thorough peer review

- No space constraints or color figure charges

- Immediate publication on acceptance

- Inclusion in PubMed, CAS, Scopus and Google Scholar

- Research which is freely available for redistribution 